\title{
(re)Weave: Adapting Urban Obsolescence in Syracuse
}

\author{
GREGORY MARINIC \& ZEKE LEONARD \\ Syracuse University
}

It has been over fifty years since the beginning of the decline of the American industrial city. After World War II, urban life in the United States began to fracture along social, economic, and demographic lines. The rise of the interstate highway system facilitated the simultaneous collapse of downtown retail districts; advancing urban decay stood in marked contrast to a thriving, homogeneous, trans-continental suburban culture. Today, widespread obsolescence has catalyzed and accelerated to embody the future of shrinking cities in the Rust Belt.

In Syracuse and across the Great Lakes Megaregion, current socioeconomic trends challenge the inevitability of new construction. As urban neighborhoods seek greater density, and base building opportunities become less common, shrinking cities have embraced the practicality of adaptive reuse and infrastructural interventions. An increased focus on contingency enhances the imperative for designers to view the built environment through stewardship-fostering connectivity among the environmental, economic, and social dimensions of design practice at the scale of the city. Addressing divergent issues of both urban growth and loss, adaptive practices will migrate toward the center of contemporary design discourse. Like a form of urban acupuncture, small and incisive actions facilitate broader resilient strategies within established buildings and urban forms. Such interventions offer ways to address urban obsolescence through a dynamic overlap of interdisciplinary practices that simultaneously mend and grow-reweaving a city and region by means of hybrid redevelopment practices.

In recent years, next-use opportunities for existing buildings and infrastructures have grown more lucrative, demanding, and complex. This paper presents an academic studio at the Syracuse University School of Design that engaged urban obsolescence and an aging interstate viaduct that cuts across the heart of downtown Syracuse. The paper begins with a brief overview of American suburbanization and critically reflects on the impact of Interstate 81 in Syracuse. In concludes by describing a first-year undergraduate environmental design studio that focused on infrastructural obsolescence as a pedagogical context.

\section{AN (AMERICAN) URBAN DEMISE}

After World War II, urban life in the United States began to fracture along social, economic, and demographic lines. Fueled by mass media and television culture, mainstream American consumer patterns transferred in successive rings beyond the city center to populate suburbia. Cities from coast-to-coast witnessed the emergence of entirely new forms of suburban public-commercial space shaped by urban retail fragments floating in an unstructured landscape. Downtown commercial and social experiences were displaced to the suburbs and then internalized; the complexities of metropolitan life were reconfigured into controllable interior worlds. The rise of the interstate highway system facilitated the incremental collapse of downtown retail districts. Advancing urban decay stood in marked contrast to a thriving, homogeneous, trans-continental suburban culture.

The utopian realm of suburban life has historically epitomized the American Dream, a vision of opportunity and prosperity expressed in greater autonomy, single-family home ownership, and car dependence. By the late 1950s, suburbs were where most Americans wanted to live and the rest of the world took notice. Since that time, the United States has continuously exported its suburban ideals to the rest of the world, while American suburbia has become increasingly globalized. The emergence of suburbia has had profound and enduring influences on popular culture, mass media, consumer tastes, and housing expectations. For a generation of Americans raised in the suburbs, consumer expectations of civic space were incubated in the homogenous, encapsulated worlds of shopping malls, fast food restaurants, and strip shopping centers, and thus, orphaned from any tangible connection to downtown. With the transfer of consumer buying power far beyond the center city, contemporary American culture was forged and reinforced in a throw-away landscape of post-war suburban largesse.

\section{I-81: A SAVAGE SWATH}

It has been over fifty years since the beginning of the decline of the American industrial city. The Federal Highway Act and urban renewal catalyzed and accelerated the abandonment of downtown, while the rise of suburbs-growing from mortgages underwritten by the federal government-deepened the racial, ethnic, and economic fragmentation of the city. In Syracuse, the effects of the Federal Interstate Highway Act were profound, long-lasting, and devastating. In American Urban Form: A Representative History, Sam Warner and Andrew Whittemore state, "Politicians in City Hall had the highest hopes for the federal highway program..." yet the reality in many cities was highly uneven. ${ }^{1}$ In 1944 , the passage of the Federal Highway 


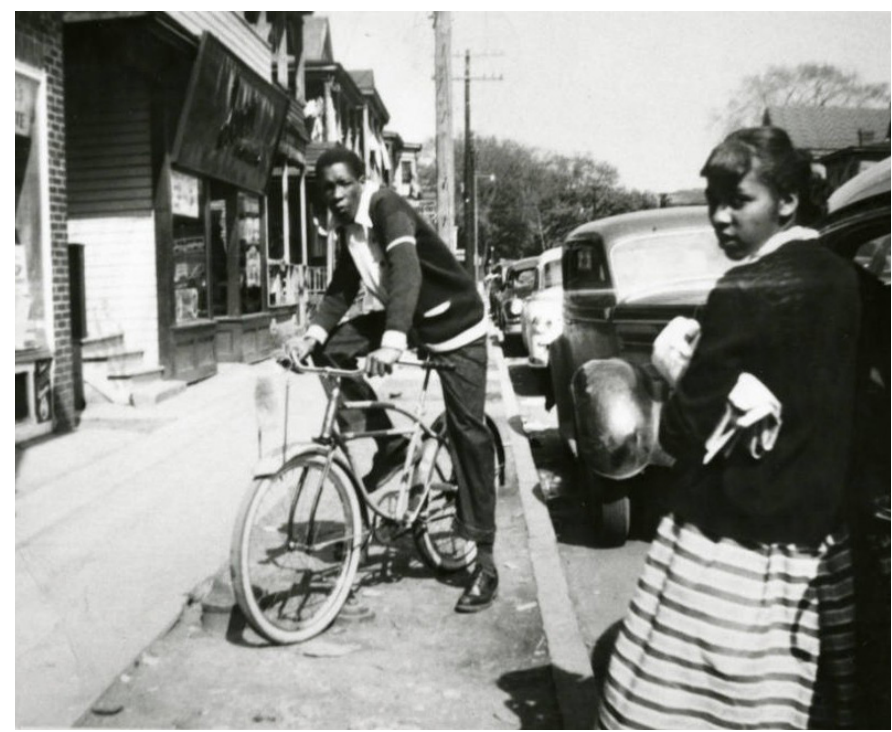

Figure 1: Old $15^{\text {th }}$ Ward, Courtesy of Onondaga Public Library

Act initiated the era of interstate highway construction which redefined urban life in the United States. ${ }^{2}$ The Urban Area Report of 1947 for Syracuse proposed a north-south highway for the metropolitan region that was later incorporated into plans for the Interstate Highway System. In 1958, the I-81 corridor though central Syracuse was aligned along Almond Street to coincide with a site designated as the Near East Side Urban Renewal Area. The elevated viaduct was constructed in three phases opening between 1959 and 1969. The construction of the final 1.4-mile elevated viaduct, was delayed due to property acquisitions and relocation of residents.

In the 1950s, Syracuse was a bustling, mid-sized manufacturing city with machining and metal-based industries, as well as producers of clay, fabric, leather products, and smaller enterprises producing a diverse range of desirable consumer goods. Although the initial plan for the north-south highway called for a modest, partially sub-grade highway through downtown, the arterial plan struck a chord with the transportation-oriented history of the city and post-war optimism. Combined with engineering difficulties emerging from early surveys for the below-grade plan, a raised highway was settled upon as the preferred route for what was then called the Penn-Can Highway connecting Pennsylvania with the Canadian border. Encouraging retailers and business owners in the downtown business district, District Department of Transportation engineer Earle E. Towlson stated that "Through Syracuse, the expressway would be tied in with the city's arterial routes." ${ }^{3}$ The chosen route via the $15^{\text {th }}$ Ward reflected urban redevelopment policies employed on a national scale in the United States that subversively disenfranchised minority groups and their neighborhoods. Local newspapers referred to the $15^{\text {th }}$ Ward as a "slum area" even though census reports indicated that it had similar employment and income levels to other working-class neighborhoods in the city. ${ }^{4}$ In this case, the difference between the $15^{\text {th }}$ Ward and other areas was the religious, ethnic, and racial characteristics of its residents; the $15^{\text {th }}$ Ward was a multi-ethnic, predominantly Jewish and African-American neighborhood.

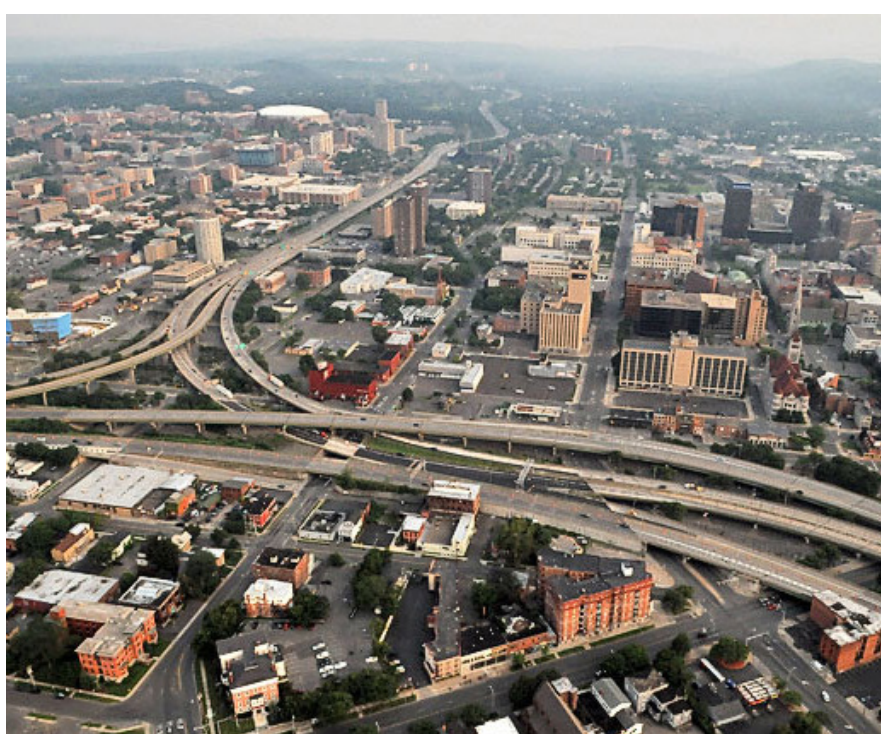

Figure 2: I-81 / I-690 Interchange, Courtesy of Onondaga Public Library

In 1958, Mayor Henninger unveiled a modernist vision of the city center with new municipal buildings, an art museum, a pedestrian plaza, and climate-controlled commercial spaces. The plan was realized in fits and starts during the ensuing years, but almost immediately had the effect of forcing the resettlement of thousands of residents to other parts of the city or suburbs. The urban renewal program in Syracuse took aim at working-class residential districts on the fringes of downtown, labeling them "blighted", however, most of the condemned residences were occupied, maintained, and valued by their inhabitants. In most cases, blocks of residences were seized, razed, and the land was redeveloped. ${ }^{5}$ Over 1,300 families were displaced due to construction of the I-81 viaduct and other urban renewal projects on the East Side. ${ }^{6}$ Furthermore, the viaduct destructively bifurcated downtown Syracuse from the campuses of Syracuse University and the SUNY College of Environmental Science and Forestry.

Although suburban shopping centers were either in the planning stages or already completed by the late 1950s, the downtown business community supported the highway plan. The promise of wealth flowing into, rather than around, the city was attractive; many merchants envisioned the new highways as a way to compete with the suburbs. Although local officials hoped highway access and abundant parking structures would draw business downtown, these infrastructures offered not only a way get to the city, but to leave. Urban expressways hastened the decentralization of the metropolis and the loss of the central business district's dominance. ${ }^{7}$

In general, displaced Jewish families benefited from their privilege as whites and migrated to middle-class neighborhoods and suburbs on the East Side of Syracuse such as Westcott, Meadowbrook, Scottholm, 


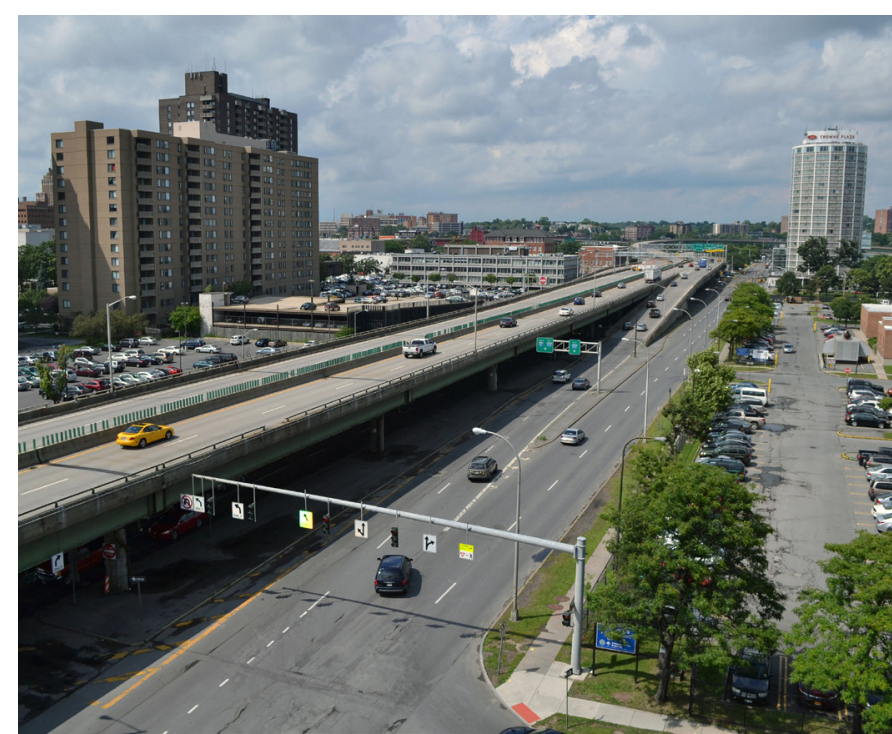

Figure 3: Aerial view of I-81 viaduct, Courtesy of Syracuse Media

Scottholm, Dewitt, and Fayetteville. At the same time, African Americans were resettled on the South Side of Syracuse into an impoverished black neighborhood. Like other controversial urban renewal projects, these federal government-sanctioned actions reflected the unspoken "negro removal" policy specifically targeting African Americans who, because of racial discrimination and discriminatory lending practices, were least able to move to the suburbs. ${ }^{8}$ Both Jewish and African American residents of the $15^{\text {th }}$ Ward vocalized their frustration and perceived inadequacies of compensation. The "fair market value" of their homes was determined not by owners, brokers, and the marketplace, but by anonymous municipal bodies serving the interests of eminent domain. Disrupting the multi-ethnic balance of the $15^{\text {th }}$ Ward increased white flight to the suburbs, while the exodus of working-class residents depleted the city's tax base and spawned further abandonment.

A combination of the planned central plaza and routing of the interstate highway created an environment for the entire removal of residences in the $15^{\text {th }}$ Ward. In its place rose a modernist urban plaza, office towers, an art museum, government offices, and high-rise apartments in the manner of Le Corbusier's Radiant City. Significant developments emerging from the ashes of an erased $15^{\text {th }}$ Ward include I.M. Pei's iconic Everson Museum of Art (1968), the Jefferson Towers apartments (1970), and the Madison Towers apartments (1985) connected by Brutalist plazas and promenades. However, as Jane Jacobs observed, "Large swatches of construction built at one time are inherently inefficient for sheltering wide ranges of cultural, population, and business diversity...". ${ }^{9}$ The monumental concrete expanses are underused during the long winter months, offering no protection from the elements or reasons to gather. And although both the commercial towers, civic center, and arts complex remain active during the day, the workforce primarily lives in the suburbs. Furthermore, the urban design principles of many renewal projects were questionable. ${ }^{10}$ These projects were characterized by stark, modernist plazas framed by impressive architecture, yet they often became known as peopleless places.

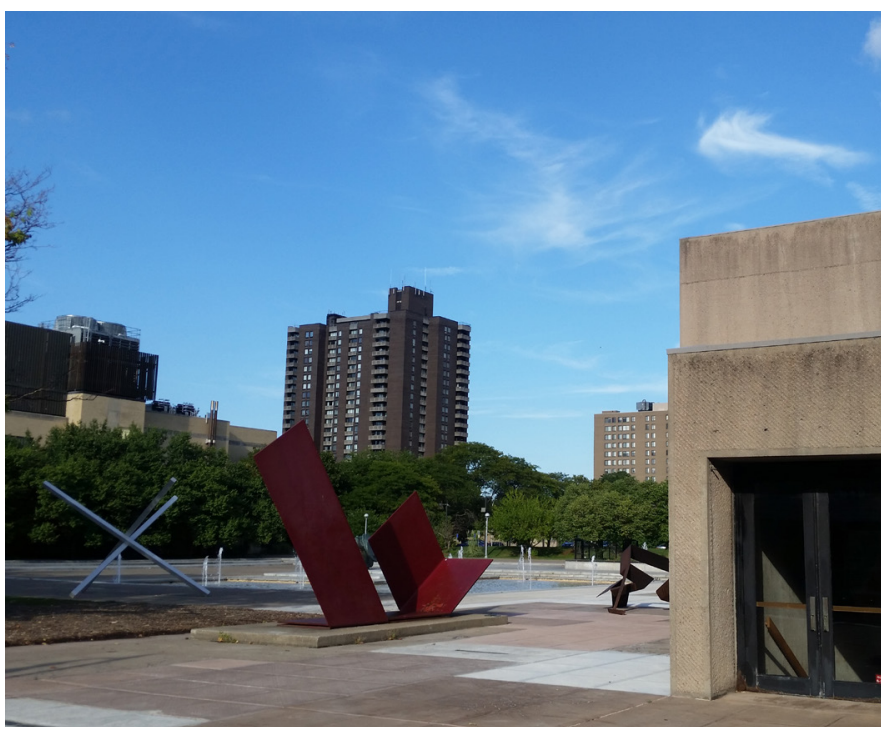

Figure 4: Everson Museum Plaza \& Jefferson Towers, Courtesy of G. Marinic

In addition, early fears that the I-81 viaduct would be a significant barrier between the campus district and downtown Syracuse have borne out completely. ${ }^{11}$ The raised roadway and the dark, damp, and forbidding paved spaces beneath it have created a notable racial, ethnic, and social division through the heart of the city. Dustin Cable of the University of Virginia's Weldon Cooper Center for Public Service visualized 2010 Census data to demonstrate the dramatic segregation of African Americans immediately west of the viaduct and white residents living in the east. ${ }^{12}$ In 2014, the non-profit organization CNY Fair Housing released a 148-page report titled "Analysis of Impediments to Fair Housing" that detailed extreme racial segregation in Syracuse due, in part, by $1-81 .{ }^{13}$

Current research documents the clear need for I-81 to be dismantled or remediated. As Jane Jacobs asserts, "In our American cities, we need all kinds of diversity, intricately mingled in mutual support. We need this so city life can work decently and constructively, and so the people of the city can sustain (and further develop) their society and their civilization." ${ }^{14}$ When Jacobs links diversity with vitality, she calls for nurturing "congenial places for a great range of unofficial plans, ideas, and opportunities to flourish."15 Today, I-81 and its urban renewal periphery represent the antithesis of human-scale community development; the current configuration works against greater density and population growth. And although the Everson Museum and its plaza offer nodes of beauty and activity, both require significant new investment and renovation. The New York Department of Transportation is currently evaluating seventeen alternative rehabilitation/remediation projects for the I-81 viaduct. ${ }^{16}$ Of these, seven proposals have passed the first round of examination which fall into three basic categories. The first type preserves the highway in its existing state, performing routine maintenance only. This option is required as a baseline by the National Environmental Policy Act. The other two options present either a new viaduct or street-level boulevard. The current options have not addressed the larger periphery of I-81 defined by significant abandonment and well established terrain vagues. 


\section{THE CHARGE: (RE)MAKING A COMMUNITY}

For marginalized populations, survival is based upon the ability for a community to reorganize and remake itself socially, economically, and spatially. In shrinking cities, resilience can take on a social dimension based upon the remobilization of existing building stock and infrastructures, as well as associated redundancies that mitigate the potential for economic collapse. The formerly dense metropolitan core of Syracuse was conceived over time in intermingled bands of residential, commercial, and industrial development. Although the center city is currently fragmented, it remains embedded with the organizational memory of urbanity. Revealing echoes of the past, many neighborhoods have undergone considerable change, migrating slowly away from segregation and abandonment toward a more socially, economically, and ethnically diverse future.

Today, downtown Syracuse contrasts considerably with its original intent. Much like the upheaval encountered by displaced persons, it is defined by unideal physical circumstances and disordered spatialities, vacancies, and voids. Even so, the recent urban regeneration of the Armory Square district offers significant potential for new forms of socio-economic growth, cultural hybridization, and urbanity. The fragmented core of Syracuse is allowing more informal commercial enterprises to percolate and prosper. Within an architecturally historic landscape, modest community needs shape an everyday environment leveraged through an accessible cache of undervalued buildings, neighborhoods, and infrastructures poised for adaptation to changing needs and desires.

The idea of fostering resilience in urban infrastructure is a strategic theme and operational goal for many cities around the world. Researchers, scholars, and practitioners in various disciplines have struggled with the notion of resilience in their respective fields for decades. What does resilience mean in terms of existing buildings or infrastructures, and more specifically, how might it be accomplished in shrinking cities? As architects, designers, and planners struggle to develop prescriptive models that guide resilient practices at the metropolitan scale - the ecological, economic, and social dimensions of resilience have become increasingly more relevant within established urban forms. More recently, the focus on resilience has shifted away from anticipation of risk and mitigation, and toward a more integrated and incremental model that promotes protective and preventative strategies. Conventional or low-tech approaches to resistance may be linked to more responsive and regenerative aspects of resilience. What does the notion of resilience mean for the adaptation of underpopulated neighborhoods and obsolete infrastructures?

One of the most vital and central aspects of resilience is the ability for neighborhoods to adequately support their own residential, commercial, social, spiritual, and cultural needs. In Syracuse, the adaptive potential of existing and undervalued buildings and infrastructures systematizes a bottom-up framework of social support for the economically disadvantaged. As a magnet for immigrant and refugee communities, Syracuse can harvest this potential for population growth and center city densification. In many cases, immigrants and refugees are independently appropriating obsolescence-the finely grained retail shops, abandoned warehouses, and residential streets of a forgotten center city host their emerging communities. Un-monumental, anti-heroic, and autonomous, such transformations reflect limited means, as well as the impact of time, collective memory, and the everyday. Considering immigration as an engine for the rebirth of central Syracuse, heterotopias-or places of otherness based on common social, cultural, or ethnic origins-actively repopulate the city center, while satisfying the broader desire to redefine space. Existing buildings serve as the primary building block for heterotopias, offering an available and accessible infrastructure for residency and mercantile activity. In central Syracuse, previously disinvested neighborhoods, such as the North Side, demonstrate an emergent vitality mobilized by its immigrant and refugee workingclass community.

\section{THE STUDIO: (RE)WEAVE}

Controversial from the beginning, the elevated viaduct of I-81 cuts a divisive path across the heart of Syracuse. Today, the viaduct that runs through the central business district is nearing the end of its useful life and must be repaired or replaced in the near future. This design research-based undergraduate studio investigated adaptive reuse and deployable architecture as a way to remediate I-81 and re-establish a diverse neighborhood that was lost to urban renewal. Rejecting tabula rasa approaches to design, these speculative projects sought to enhance and reform an existing, obsolete infrastructure through introduction of public space, pedestrian amenities, and bicycling infrastructure. The studio is a case study on the impact of infrastructural obsolescence on shrinking cities, the reform of urban renewal largesse, and the pursuit of resilient growth strategies mobilized through incremental means. It sought to embrace imperfection and reduce flows to the waste stream by reactivating underutilized structures.

Inspired by Henri Lefebvre's Right to the City and his negotiations between old and new spatial/urban forms - this studio sought to engage infrastructural obsolescence from the bottom-up and the inside-out, rather than the top-down; it introduced undergraduate environmental design students to adaptive design practices toward repopulating the center city. Students identified user-groups with multiple needs, and worked to enhance existing support systems in proposed co-housing communities. Taking cues from various histories and successful infrastructural adaptation projects such as the HighLine in New York, the 606 in Chicago, and the BeltLine in Atlanta, the studio was based upon a hypothetically deprogrammed I-81 viaduct. Students investigated renewal through the lens of preservation and transformation of the I-81 elevated expressway viaduct. Students were encouraged to critique the controversial nature of the viaduct and to envisage new communities that bridged the divide without erasing its history. Using shipping containers as a deployable and modular form of architecture, this project required interventions that ranged in scale from individuals-to-community and from the human body-to-the city. 

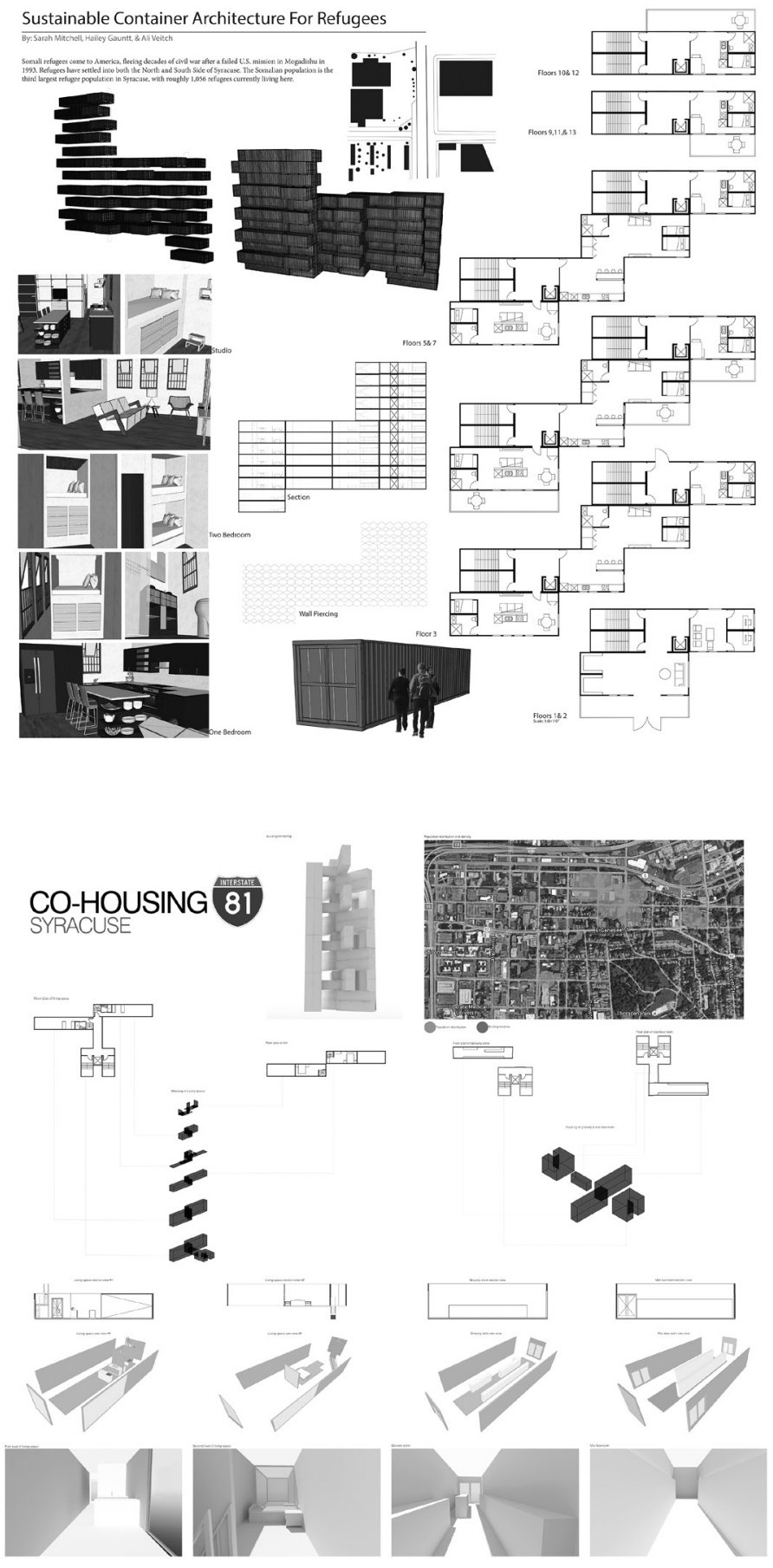

Figure 5: 'Sustainable Container Architecture for Refugees', H. Gauntt, S. Mitchell, \& A. Veitch; 'Co-Housing 81', K. Wang, J. Zhu, \& C. Zhou
As a large-scale infrastructure, reimagining I-81 as a new residential community offered students the opportunity to serve multiple user groups of various abilities, desires, generations, and socioeconomic backgrounds. Working in groups of three, they began with a thorough site documentation and analysis of Syracuse demographics. Student teams developed unique, blended programs which blurred boundaries between interior and exterior, fixed and deployable, old and new; they addressed a broad scope of research engaging historical, contextual, cultural, and social parameters of design. Co-housing proposals were required to interact with the de-programmed I-81 viaduct and to rethink it as a multi-functional, all-season pedestrian zone. Housing proposals adapted this existing infrastructure with regard to ecology, landscape systems, and green design. Students envisioned diverse new communities offering longterm resilience built upon the ruins of a divisive infrastructure.

\section{REFLECTION}

In Naked City: The Death and Life of Authentic Urban Places, Sharon Zukin interrogates the role of the "authentic" city in the transformation of Brooklyn by the creative class. In a similar manner, Syracuse demonstrates how tertiary cities of the Great Lakes Megaregion and Northeast United States can respond to shifting paradigms through re-densification strategies. Immigrants, displaced persons, and members of the creative class have been incrementally re-inhabiting and re-interpreting post-industrial spatial remnants, and thus, jump-starting the revitalization of the center city. Emblematic of the issues confronting Rust Belt cities, Syracuse continues to grapple with the impact of shifting economies, a diminished manufacturing base, and shrinking population. This studio sought to introduce students to such complexities early in the undergraduate curriculum. Although the project posed a significant design challenge for second semester undergraduate students, it opened up a rich dialogue that has grown in subsequent semesters to address obsolescence throughout the environmental design curriculum.

\section{ENDNOTES}

1. Sam Bass Warner and Andrew H. Whittemore, American Urban Form, $A$ Representative History, MIT Press, Cambridge, 2012, p 120

2. Ibid. p 120

3. "Air Surveys to Fix North-South Route" (Syracuse Herald-Journal,19 May 1955)

4. Ganley, Joseph V. "Stateway Elevation Fear Unfounded." Syracuse HeraldAmerican, 27 Apr 1958

5. Warner \& Whittemore, p 121

6. "Only 718 Units In Housing For Uprooted." (The Post-Standard, 5 May 1957)

7. Warner and Whittemore, Urban Form $\mathrm{p} 121$

8. Sharon Zukin, The Naked City; The Death and Life of Authentic Places, Oxford University Press, 2010, p 11

9. Jane Jacobs, The Death and Life of Great American Cities, Random House, 1961.

15. Ibid.

11. "Empire Stateway Link Shifted to Almond St." (The Post-Standard, 22 Oct. 1958)

12. http://demographics.coopercenter.org/DotMap/index.html

13. http://media.syracuse.com/news/other/2014/11/17/CNY-Fair-Housing-Report.

14. Jacobs, p 241

15. Ibid.

16. https://www.dot.ny.gov/i81opportunities/alternatives 